\title{
CONTRIBUIÇÃO ESPECIAL
}

\section{KEYNES AND ECONOMIC DEVELOPMENT}

\section{A. P. Thirlwall}

\section{RESUMO}

Discute-se neste artigo que, embora Keynes não tenha sido um economista do desenvolvimento no sentido convencional, seu aparato teórico e pensamento sobre como as economias capitalistas funcionam e suas propostas em Bretton Woods, em 1944, para uma nova ordem monetária internacional têm relevância para os debates que ocorrem hoje sobre desenvolvimento econômico, particularmente no que diz respeito à liberalização financeira, o papel do governo em promover o nível de emprego e as conseqüências sobre instabilidade de preços de produtos primários.

Palavras-chave: Keynes, desenvolvimento econômico, liberalização financeira, desemprego, instabilidade de preços de produtos primários.

\section{ABSTRACT}

It is argued in this paper that although Keynes was not a development economist in the conventional sense, his theoretical apparatus and thinking about how capitalist economies function, and his proposals at Bretton Woods in 1944 for a new international monetary order, have relevance for the debates that take place today in development economics, particularly regarding financial liberalisation, the role of government in achieving full employment and the consequences on primary product price instability.

Key words: Keynes, development economics, financial liberalisation, unemployment, primary product price instability.

JEL classification: 011, 023, 019 .

$\S$ University of Kent. Contact address: Department of Economics, Keynes College, University of Kent, Canterbury, Kent CT2 7AN, U.K. E-mail: at4@kent.ac.uk.

Recebido em junho de 2007. Aceito para publicação em setembro de 2007. 


\section{INTRODUCTION}

Keynes was not a development economist as the description is used today. He did not address directly issues of national or international poverty and income distribution; only indirectly through his focus on unemployment which has always been, and remains, a major cause of poverty in both developed and developing countries. It is no accident that the one billion workers identified by the International Labour Organisation (ILO) in Geneva as unemployed and underemployed matches almost exactly the one billion people measured by the World Bank as living in extreme poverty on less than $\$ 1$ a day. They are more or less the same people.

Even though Keynes was not a development economist in the conventional sense, his theoretical apparatus and thinking about what drives capitalist economies, formalised in his magnum opus, The General Theory of Employment Interest and Money (1936), and his proposals at the Bretton Woods Conference in 1944 for a new international monetary order (which were largely ignored), do have relevance for the debates that take place today in development economics. In this short article, I attempt to get into Keynes's mind and to try and guess what he might have said and recommended on some of the pressing issues facing developing countries (and the world economy) today.

\section{KEYNES-HARROD GROWTH THEORY}

When I teach growth and development economics, one of the first things I do is to teach the simple Harrod (1939) growth model, and ask the students where they think less developed countries (LDCs) fit into the picture. Harrod distinguished three different growth rates: the actual growth rate $(g)$; the warranted growth rate $\left(g_{w}\right)$, and the natural growth rate $\left(g_{n}\right)$.

The actual growth rate is defined as:

$$
g=s / c
$$

where $s$ is the savings ratio $(S / Y)$, and $c$ is the actual incremental capital-output ratio $(d k / d Y)=$ $(I / d Y)$. Equation (1) is a useful identity expressing the ex-post equality between saving and investment in the national accounts. In other words, any country's growth rate is by definition equal to its savings ratio divided by the ratio of new investment (including inventory investment) to the change in output.

The warranted growth rate is defined as:

$$
g_{w}=s / c_{r}
$$

where $c_{r}$ is the required incremental capital-output ratio; that is, the required amount of investment to produce an additional flow of output $\left(I_{r} / d Y\right)$, given the prevailing technology and the rate of interest. The warranted growth rate is therefore the growth rate required for planned investment to match planned saving to keep the economy on a steady growth path so that investors do not revise their investment plans upwards or downwards, thereby ensuring a moving equilibrium through time.

The natural rate of growth is defined as:

$$
g_{n}=l+t
$$


where $l$ is the rate of growth of the labour force and $t$ is the rate of growth of labour productivity determined by technical progress. This is the maximum growth rate achievable, or the 'social optimum' growth rate, as Harrod called it.

Let us ignore for the moment the actual growth rate $(g)$, and focus on the relation between the warranted $\left(g_{w}\right)$ and natural $\left(g_{n}\right)$ growth rates. Almost certainly for most LDCs, $g_{n}>g_{w}$ because labour force growth is high; labour productivity growth is relatively high; the savings ratio is low, and the capital-output ratio is relatively high (reflecting a low productivity of investment). Let us give an example: suppose $l=2$ percent per annum (p.a.); $t=3$ percent p.a.; $s=10$ percent, and $c_{r}=4$; then $g_{n}=2+3=5$ percent and $g_{w}=10 / 4=2.5$ percent. This gives a serious imbalance between the growth of the effective labour force and the rate of capital accumulation, which Keynes would have recognised as a major cause, or source, of unemployment and underemployment in LDCs - not of the involuntary variety as defined in The General Theory, but of the structural variety caused by a lack of capital for labour to work with (at least without a change in the techniques of production).

He would have recognised this serious imbalance because in 1937, in a paper to the Eugenics Society on "Some Economic Consequences of a Declining Population", he first identified the opposite imbalance in rich countries of $g_{w}>g_{n}$, thus anticipating Harrod's 1939 model (see Thirlwall, 1987, 2007). Keynes didn't use the terms 'natural' and 'warranted' growth rates, but he expressed the worry that if population growth in developed countries fell to zero (as it was predicted to do in the future because the net reproduction rate in the 1930s had fallen below one), there would not be enough induced investment to match planned saving i.e. the 'natural' growth rate might be only, say, 1 percent due to productivity growth (or technical progress) while the supply of capital, due to saving (i.e. the 'warranted' growth rate) might be, say, 3 percent. Planned saving would exceed planned investment $\left(g_{w}>g_{n}\right)$ which would be a recipe for stagnation. In the event, secular stagnation and population decline was allayed by war and its aftermath.

This simple Keynes-Harrod framework turns out to be a very useful pedagogic device for understanding the various policy options open to governments in LDCs faced with a growth of the effective labour force in excess of the growth of capital accumulation, which is illustrated in Figure 1.

Figure 1- The relation between the natural and warranted growth rates

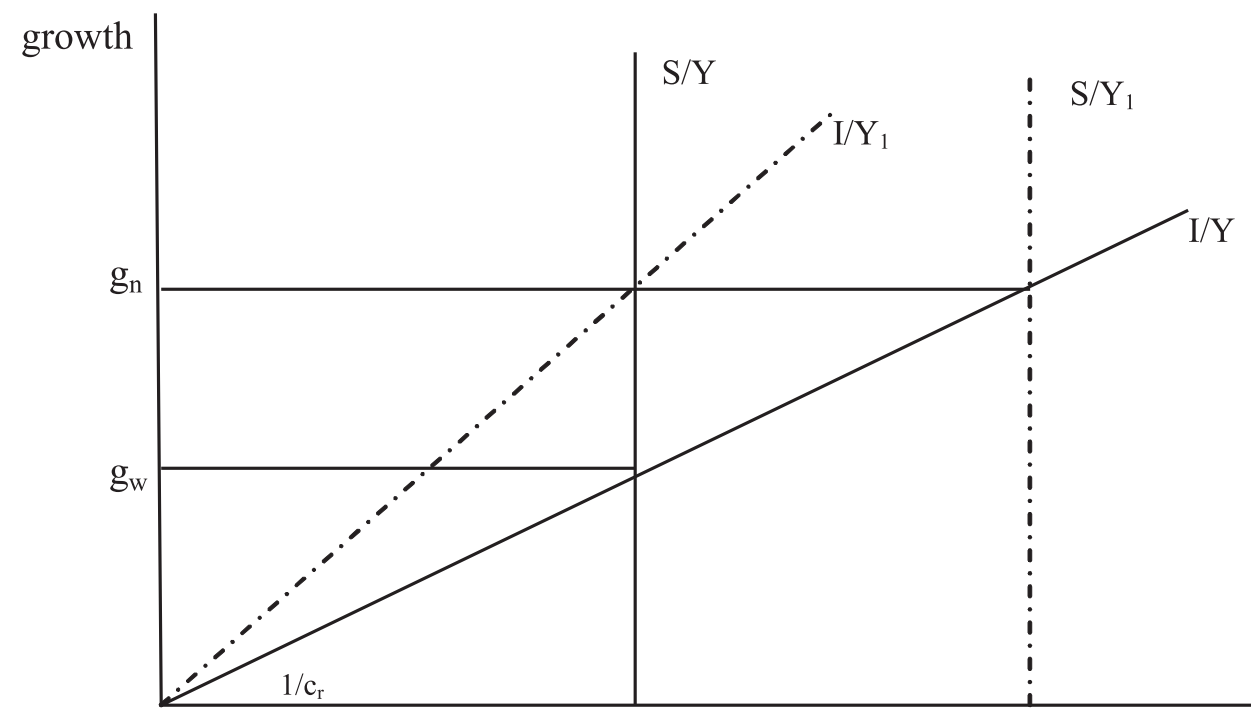


The warranted growth rate $\left(g_{w}\right)$ is defined where the planned investment schedule $(I / Y)$ and planned saving schedule $(S / Y)$ cross; and the natural growth rate $\left(g_{n}\right)$ is composed of $l+t$. If $g_{n}$ $>g_{w}$ (as depicted), or $l+t>s / c_{r}$, there are two policy options on the left hand side of the equation. The first is to reduce $l$, the rate of growth of the labour force, but this is not feasible in the short run. It gives a justification, however, for population control policies to tackle the problem of excess labour supply in the longer run. The second policy option is to reduce $t$, the rate of growth of labour productivity, but this would reduce the growth of living standards for those in work, and impair the competitiveness of the economy. For a given growth of output, there is always a conflict between the growth of employment and the growth of living standards.

On the right hand side of the equation, attempts can be made to increase the saving ratio (S/ Y) by monetary and fiscal policy, but Keynes would surely have been a severe critic of the financial liberalisation paradigm that prior saving is necessary for investment to take place. One of Keynes's most fundamental messages is that what drives a capitalist economy is the decision to invest, not the decision to save. Saving must ultimately fund investment, but it is not the function of saving to finance investment. That is the role and purpose of the banking system, and the provision of credit. This important consideration has implications for interest rate policy in developing countries. The financial liberalisation school argue for higher real interest rates to raise the savings ratio, but high real interest rates discourage investment. Keynes would want low real interest rates to encourage investment, and to keep down operating costs. Credit rationing, if necessary, would be a small price to pay. ${ }^{1}$ But what is the optimum real rate of interest? There is no easy answer to this question, but even within the financial liberalisation model, it could be negative if liquidity preference is high, and the desire to invest is weak. Research on the rate of interest below which the relation between the interest rate and investment is positive (because investment might be constrained by saving), and above which it is negative, shows a switch-point close to zero (see Warman and Thirlwall, 1994 and references cited there). This is what Maxwell Fry (1997) also implicitly finds in a large study across countries of the relation between GDP growth and real interest rates. The relation is a quadratic, with GDP growth highest in countries where the real interest rate is close to zero.

Keynes would also have had something to say about tax policy and tax reform in developing countries; that is, about compulsory saving to raise the overall savings ratio. Tax effort, as measured by the differences between actual tax revenue and taxable capacity (predicted on the basis of per capita income, the distribution of income, and the share of trade and industry in GDP), is weak in many LDCs (see Thirlwall, 2005, Table 14.3).

There is also the possibility of forced saving; that is, governments investing on society's behalf, and financing the expenditure by expansion of the money supply. This is sometimes known as the 'inflation tax' which Keynes described in his Tract on Monetary Reform (1923) as: "a tax which the public finds hard to evade and even the weakest government can enforce when it can enforce nothing else". This is not an apologia for inflation but there is little doubt where his preference curve would lie compared to today's orthodoxy, preached by all the major international financial institutions and Central Banks around the world, that a precondition for growth and development is price stability. In his Essays in Persuasion (1931), Keynes described unemployment as unjust and inflation as inexpedient, but "it is worse in an impoverished world to provoke unemployment than to disappoint the rentier". In practice, there is no scientific evidence that price stability is a precondition for faster

1 In any case, even in 'free' markets, there is likely to be credit rationing because of asymmetric information and adverse selection (Stiglitz and Weiss, 1981). 
growth (see later), but, in any case, inflation is not the inevitable result of monetary expansion if an economy is growing, and the demand to hold money per unit of income is increasing as monetisation of an economy takes place. The simple quantity theory of money (based on the equation of exchange) tells us that if an economy is growing at 3 percent p.a., and the demand to hold money per unit of income is growing at, say, 5 percent p.a., the supply of money can grow at 8 percent p.a. without prices rising. This can be appropriated by governments for investment purposes. Moreover, if the public expenditure finances projects which help the poor, such as irrigation and infrastructure projects in the rural sector and housing in the urban sector, the 'inflation tax' can be egalitarian. Poor countries, with high unemployment, desperately need government investment in labour intensive public projects which not only absorb labour but also increase the supply capacity of the economy at the same time.

Finally, on the right hand side of the inequality between $l+t$ and $s / c_{r}$, there is the issue of the incremental capital-output ratio, $c_{r}$. A reduction in $c_{r}$ will move $g_{w}$ towards $g_{n}$ by pivoting upwards the $I / Y$ curve to $I / Y_{1}$ (see Figure 1). The capital-output ratio is a measure of the capital (or labour) intensity of production techniques. The question for poor countries is can they move towards the use of more labour intensive techniques without reducing output and the level of saving? There is evidence from the work of Pack (1982) (and others) that firms can substitute capital for labour and stay on the 'efficiency frontier', provided other cooperating factors of production are available, as illustrated in Figure 2.

Figure 2 - The choice of techniques

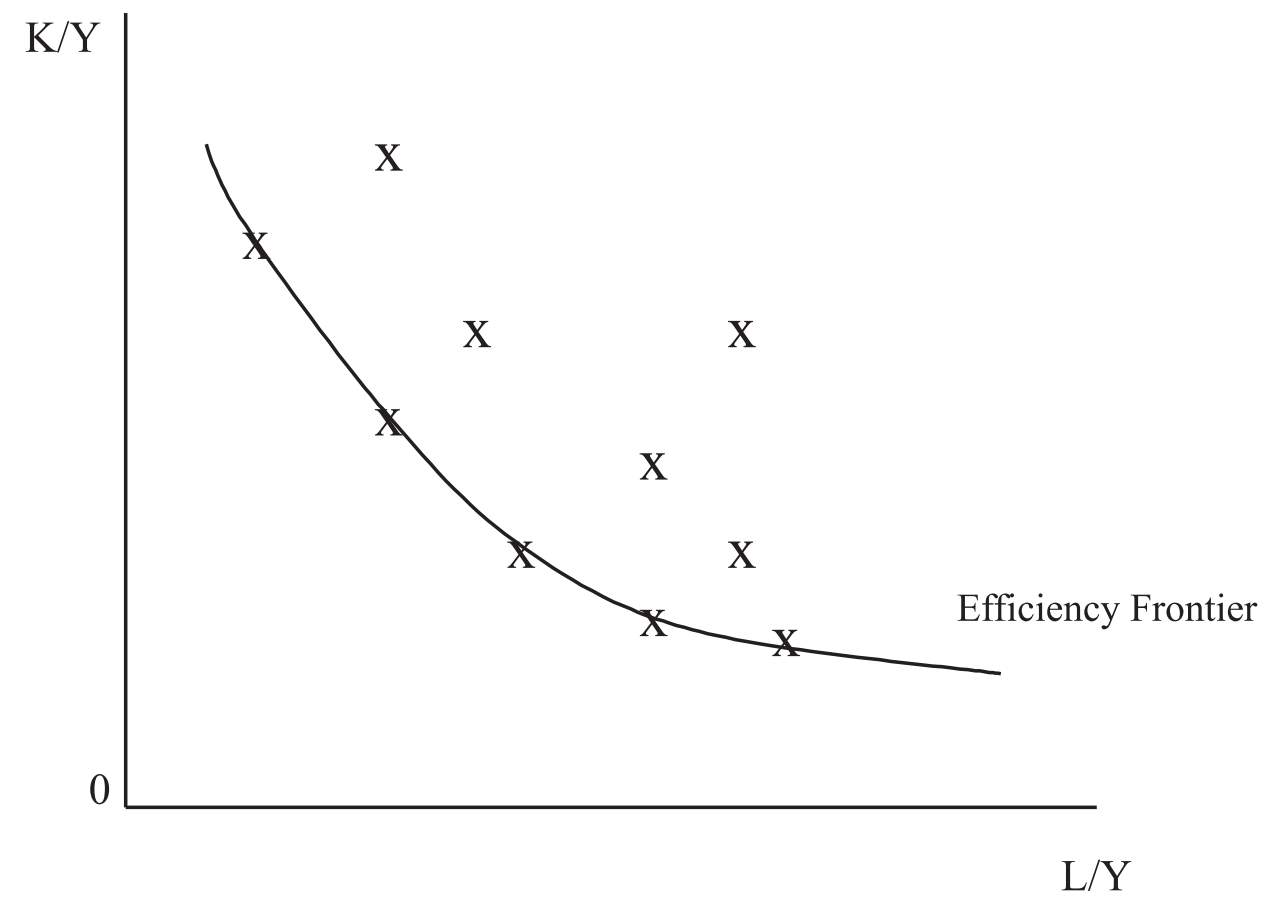

Take, for example, a fairly homogenous commodity, such as paint. The scatter points in Figure 2 show the combinations of capital per unit of output $(K / Y)$ and labour per unit of output $(L / Y)$ that firms use in different countries to produce paint. Joining up the points closest to the origin (which are clearly the most efficient firms) gives the 'efficiency frontier' and shows that there 
is a spectrum of techniques that countries can choose from given the knowledge and 'know-how'. It is sometimes argued, however, that moving down the efficiency frontier to more labour intensive techniques will reduce national saving because the share of wages in national income will increase, and the propensity to save out of wages is less than out of profits. This is not necessarily the case for a number of reasons. Firstly, the propensity to consume out of wages and profits may not differ much; secondly, the alternative to more employment of unemployment reduces personal and family saving; thirdly, consumption itself can be 'productive' by improving nutrition and stimulating effort, and lastly governments can prevent consumption from rising using tax policy. As Amartya Sen (1969) argues in his discussion of the choice of techniques in LDCs: "the total amount of income to be saved can be determined by the planner in any way he likes. If this is true then the link snaps between choice of techniques and the proportion of income saved. The technical choice may be made with the main purpose of maximising output [and employment], and the proportion of the output to be invested can be decided at a separate stage".

\section{THE DETERMINANTS OF ACTUAL GROWTH PERFORMANCE}

Faster growth of national income is absolutely essential for poverty reduction, and for achieving the Millennium Development Goal of halving world poverty by the year 2015 compared with its level in 1990. The question is whether faster growth is demand-constrained or supply-constrained, or a combination of both? This is where the debate between 'old' and 'new' (neoclassical) growth theory and Keynesian growth theory starts. In orthodox growth theory for the closed economy (Solow, 1956), supply creates its own demand. There is no independent investment function. Long run growth is determined by the exogenously given growth of the labour force in efficiency units (Harrod's natural rate of growth). Because of the neoclassical assumption of diminishing returns to capital, investment does not matter for long run growth; and there are no demand constraints either. In 'new' (endogenous) growth theory, investment does matter for long run growth because the assumption of diminishing returns to capital is relaxed, but there are still no demand constraints. Growth is endogenous in the sense that it is not simply exogenously determined by the effective labour supply, not in the sense that growth is endogenous to demand. When the neoclassical growth model is extended to the open economy, the balance of payments is ignored. It is somehow assumed to look after itself without income adjustment. There is no foreign exchange constraint recognised.

Likewise in orthodox trade theory, the balance of payments is ignored. The gains from trade are measured from the supply side; that is, by how much trade augments a country's real resources through the pursuit of comparative advantage. The monetary consequences of trade, or the balance of payments effects of different patterns of resource allocation, are forgotten. Trade is always mutually beneficial between countries whatever the structure of production and the pattern of trade dictated by comparative advantage. Continuous full employment is assumed, so that there are no welfare losses from unemployment in the process of resource reallocation.

One of the things that I have tried to do in my own writing on growth in developing countries (Thirlwall, 1974, 1986, 2002, 2005) is to put demand into development theory as a driving force; and to argue that demand constraints may operate long before countries reach full capacity utilisation. The evidence for this is the massive surplus of labour and the fact that capital capacity is rarely fully utilised, often because countries lack the foreign exchange to buy spare parts. Develop- 
ing countries certainly suffer from supply bottlenecks of various kinds, including poor infrastructure and lack of skills and knowledge, but this does not mean that demand is not also important in determining the growth performance of nations. In particular, in the open economy, foreign exchange is a major constraint on the growth of output. There are not many developing countries (apart from China and those flushed with oil) that could not grow faster given the greater availability of foreign exchange.

Over the last thirty years, I and colleagues (e.g. Thirlwall and Hussain, 1982; McCombie and Thirlwall, 1994, 2004) have developed a balance of payments constrained growth model, both in a simple form, and including capital flows and terms of trade effects, as an alternative model to the neoclassical supply-side model for understanding differences in the growth performance of nations. The extended model permits the disaggregation of the growth of national income into four component parts: (i) the effect of the growth of exports driven by world output growth and the income elasticity of demand for exports; (ii) the effect of terms of trade, or real exchange rate, changes on the balance between export and import growth; (iii) a pure terms of trade effect, and (iv) the effect of the growth of real capital flows (in or out). The model turns out to be a very versatile one, with a lot of explanatory power. It has been applied to Brazil by Ferreira and Canuto (2003), also including the effect on growth of interest rate payments on past international debt. For many countries the simple rule holds that long run growth can be predicted by the rate of growth of export volume divided by the income elasticity of demand for imports. This turns out to be the dynamic analogue of the static Harrod trade multiplier result derived by Harrod in 1933, that if long-run balance of payments equilibrium on current account is a requirement, and the real terms of trade or exchange rate remain constant, national income is a linear multiple of the level of exports relative to the marginal propensity to import.

In an open economy, within a balance of payments framework, demand fluctuations and demand constraints come in a variety of forms, triggered by different factors. One is terms of trade fluctuations which affect the balance of payments directly, and also government revenue and private investment. Before and during the Second World War, Keynes had a lot to say about the detrimental effects on the world economy of commodity price fluctuations and he wanted a 'Commod Control' scheme to be established at Bretton Woods to stabilise the price of primary commodities within, say, a 10 percent band around an agreed 'normal' price. In a paper presented at the British Association for the Advancement of Science in 1938, published in the Economic Journal (Keynes, 1938), Keynes noted that for the four commodities of rubber, cotton, wheat and lead, the price had fluctuated by 67 percent in the previous ten years, and was led to remark: "assuredly nothing can be more inefficient than the present situation whereby the price is always too high or too low and there are frequent meaningless fluctuations in the plant and labour force employed." Then in a Memorandum in 1942 (Moggridge, 1980), Keynes remarked: "one of the greatest evils in international trade before the war was the wide and rapid fluctuations in the world price of primary commodities - it must be the prime purpose of control to prevent these wide fluctuations". Keynes believed, with some justification, that a 'Commod Control' scheme would make a major contribution to curing the international trade cycle. Indeed, the injection and withdrawal of purchasing power by buying up commodities when prices are more than say, 10 percent below their agreed level and selling when prices are more than, say, 10 percent above the agreed level would operate much more immediately and effectively than public works. Keynes remarked (Moggridge, 1980): 
"at present, a falling off in effective demand in the industrial consuming countries causes a price collapse which means a corresponding break in the level of income and of effective demand in the raw material producing countries, with a further adverse reaction, by repercussion, on effective demand in the industrial countries; and so, in a familiar way, the slump proceeds from bad to worse. And when the recovery comes, the rebound to excessive demands through the stimulus of inflated price promotes, in the same evil manner, the excesses of the boom." (p. 121).

This sentiment has recently been reiterated in a major study by Cashin and McDermott (2002) at the IMF of fluctuations in real commodity prices over the last 130 years. They say:

"although there is a downward trend in real commodity prices, this is of little policy relevance, because it is small compared to the variability of prices. ${ }^{2}$ In contrast, rapid, unexpected and often large movements in commodity prices are an important feature of their behaviour. Such movements can have serious consequences for the terms of trade, real incomes and fiscal position of commodity-dependent countries, and have profound implications for the achievement of macroeconomic stabilisation."

They identify thirteen occasions since 1913 when the annual price change was more than 20 percent in one year. This is serious volatility. They also find that average price slumps last longer than price booms; 4.2 years compared to 3.6 years.

Kaldor (1976) adopted Keynes's position and argued that primary product price fluctuations cause deflationary bias in the world economy because when prices fall this reduces the purchasing power of primary product producers and lowers the demand for industrial goods; and when commodity prices rise this also causes industrial goods' prices to rise and governments then deflate demand. Kaldor (1996) also showed in a two-sector model of agriculture and industry that unless the terms of trade between the two sectors are in equilibrium, industrial growth will either be supply-constrained if agricultural prices are 'too high', or demand-constrained if agricultural prices are 'too low'. The role of the terms of trade is to equilibrate supply and demand in both markets simultaneously, but there is no guarantee in a free market that the terms of trade will not overshoot either upwards or downwards following an autonomous shock to supply or demand in either market. Kaldor supported Keynes's idea of a 'Commod Control' scheme for important primary products, financed by the use of Special Drawing Rights (SDRs).

Another source of deflationary bias in the world economy are the programmes of the IMF and World Bank in developing countries. IMF conditionality and World Bank Structural Adjustment Programmes in poor countries were always euphemisms for deflation because both institutions misunderstand the nature of balance of payments difficulties and inflation in these countries. Balance of payments deficits are associated with countries 'living beyond their means', whereas, in practice, the deficits are inherent in the structure of production and trade (Thirlwall, 2006). Because the income elasticity of demand for LDC exports is relatively low (primary products are subject to Engel's Law), and the income elasticity of demand of their imports is relatively high, deficits are inevitable if the LDCs attempt to grow as fast as developed countries. Under the pres-

2 I don't agree with this judgement, but that is a separate issue. 
ent international economic order, it is deficit countries that are penalised; never surplus countries. Keynes wanted symmetry of adjustment with both deficit and surplus countries treated equally, but oppositely. In his "Proposals for an International Clearing Union" (Keynes, 1943) he described the aim of his Plan as "the substitution of an expansionist, in place of a contractionist, pressure on world trade - we need a system possessed of an internal stabilising mechanism, by which pressure is exercised on any country whose balance of payments with the rest of the world is departing from equilibrium in either direction, so as to prevent movements which must create for its neighbours an equal but opposite want of balance" (p. 5). Keynes's proposal was therefore that each member country should pay to the Reserve Fund of the Clearing Union 1 percent of its debits or credits in excess of 25 percent of its quota, and a further 1 percent if its debits or credits exceeded 50 percent of its quota. Keynes referred to his system as looking on "excessive credit balances with as critical an eye as excessive debit balances, each being indeed the inevitable concomitant of the other." (p. 7). "The objective is that the creditor should not be allowed to remain entirely passive." (p. 17). Indeed, the Governing Board of the Clearing Union should be empowered to discuss with countries in credit measures to expand demand; appreciate the currency; reduce tariffs, and to give international development loans, with the Board having the ultimate discretion. If the Keynes Plan had been adopted at Bretton Woods, all this would have applied to the oil exporting countries in the 1970s, which would have avoided the unloading of such large surpluses on the private capital markets and the subsequent debt problems of the recipients, and also it would have applied to countries in the developed world persistently in surplus, notably Japan and Germany, and now China.

Likewise, inflation in LDCs is regarded by the IMF and World Bank as demand inflation to be 'cured' by monetary and fiscal stringency, whereas in practice much inflation in developing countries is of the structural variety caused by bottlenecks in the productive system and by structural change (with prices much more flexible upwards than downwards). Attempting to control structural inflation (or a cost-push inflation for that matter) using deflationary aggregate demand policies simply slows growth, causes more unemployment and thwarts the development process. Structural bottlenecks (and costs) need to be addressed directly.

But in any case, there is no convincing scientific evidence that price stability is a necessary condition for more rapid growth and development. On the contrary, research from a variety of sources across large samples of countries for different time periods by Bruno (1995), Sarel (1996), Ghosh and Phillips (1998), and Pollin and Zhu (2006) shows growth to be maximised in the range of 5 to 10 percent inflation for LDCs. The price of financial conservatism may well be stagnation (which has been evident for some time in the core countries of the European Union (see Thirlwall, 2007)).

In retrospect, it is a great pity that Keynes's Plan for an International Clearing Union was not adopted at Bretton Woods in 1944, which would have had the power to create money for international, collectively agreed, purposes. ${ }^{3}$ Some of these purposes would have been: intervention in commodity markets to stabilise the price of primary commodities; aid to poor countries that need resources, to be spent in developed countries with spare resources (there is such a thing as a 'free lunch'), and 'aid for trade' to enable countries to seek out new areas of comparative advantage, because ultimately structural change is the only solution to poverty and underdevelopment.

3 Keynes used to joke that his proposal for a bank was called a Fund (the IMF), and what is, in fact, a fund is called a Bank (the World Bank). 


\section{CONCLUSION}

In 1980 Robert Lucas pronounced the death of Keynesian economics. He wrote : 'one cannot find good under-forty economists who identify themselves or their work as Keynesian. Indeed, people often take offence if referred to as Keynesians. At research seminars, people don't take Keynesian theorising seriously any more; the audience starts to whisper and giggle at one another' (Lucas, 1980). For a future Nobel prize-winner in economics, this was a silly thing to say. Not only is the Keynesian model of how capitalist developed economies function alive and kicking (witness how aggregate demand policies have reduced unemployment in the US without accelerating inflation), but his ideas concerning the functioning of the world economy are as relevant today as they ever were when he articulated them before and during the Second World War. Lucas should buy the thirty volumes of Keynes's Collected Writings and digest them before poking fun at those who draw inspiration from their insights. After all, Betrund Russell (no mean intellect himself) described Keynes 'as the cleverest man he ever met'. Commodity price instability continues to plague developing countries and the world economy, as does the free movement of short term speculative capital which Keynes believed served no useful economic or social purpose. Keynes recognised the difficulties posed by foreign exchange constraints, which led to the inclusion of a 'scarce currency clause' in the Articles of Agreement of the IMF (although it has never been used against surplus countries). If there was ever a new Bretton Woods to serve better the needs of poor countries, it would need to pay attention to all the things highlighted by Keynes in his 1943 Plan, which still need to be addressed for a fairer and more stable world international economic order.

\section{BIBLIOGAPHY}

CASHIN, P.; MCDERMOTT, C. J. The long-run behaviour of commodity prices: small trends and big variability. IMF Staff Papers, v. 49 n. 2, 2002.

FERREIRA, A.; CANUTO, O. Thirlwall's Law and foreign capital in Brazil. Momento Econômico, Jan.Feb. 2003

FRY, M. In favour of financial liberalisation. Economic Journal, May, 1997.

GHOSH, A.; PHILLIPS, S. Inflation may be harmful to your growth. IMF Staff Papers, Dec., 1998

HARROD, R. International economics. London: Macmillan, 1933.

An essay in dynamic theory. Economic Journal, Mar. 1939

KALDOR, N. Inflation and recessions in the world economy. Economic Journal, Dec. 1976.

Press, 1996

Causes of growth and stagnation in the world economy. Cambridge: Cambridge University

KEYNES, J. M. A tract on monetary reform. London: Macmillan, 1923.

. Essays in Persuasion. London: Rupert Hart-Davis, 1931.

. The general theory of employment, interest and money. London: Macmillan, 1936.

Some economic consequences of a declining population. Eugenics Review, Apr. 1937. 

1938.

. The policy of government storage of foodstuffs and raw materials. Economic Journal, Sep.

. Proposals for an international clearing union. H.M.S.O. London, April 1943. (Cmnd Paper 6437). Reprinted in: THIRLWALL, A. P. (Ed.). Keynes and economic development. London: Macmillan, 1987.

LUCAS, R. The death of keynesian economics. Issues and Ideas, Winter 1980

McCOMBIE, J.; THIRLWALL, A. P. Economic growth and the balance of payments constraint. London: Macmillan, 1994.

. Essays on balance of payments constrained growth. London: Routledge, 2004.

MOGGRIDGE, D. (Ed). The collected writings of J. M. Keynes, vol. XXVII: activities 1940-1946 shaping the post-war world: employment and commodities. London: Macmillan, 1980.

PACK, H. Aggregate implications of factor substitution in industrial processes. Journal of Development Economics, Aug. 1982.

POLLIN, B.; ZHU, A. Inflation and economic growth: a cross-country nonlinear analysis. Journal of Post Keynesian Economics, Summer 2006.

SAREL, M. Non-linear effects of inflation on economic growth. IMF Staff Papers, Mar. 1996

SEN, A. Choice of technology: a critical survey of a class of debates. In: UNIDO. Planning for advanced skills and technology. New York: UNIDO, 1969.

SOLOW, R. A contribution to the theory of economic growth. Quarterly Journal of Economics, Feb. 1956.

STIGLITZ, J.; WEISS, A. Credit rationing in markets with imperfect information. American Economic Review, June 1981.

THIRLWALL, A. P. Inflation, saving and growth in developing economies. London: Macmillan, 1974. June 1986.

. A general model of growth and development on Kaldorian Lines. Oxford Economic Papers,

. Keynes, economic development and the developing countries. In: . (Ed.). Keynes, and economic development. London: Macmillan, 1987.

. The nature of economic growth: an alternative framework for understanding the performance of nations. Cheltenham: Edward Elgar, 2002.

. Growth and development: with special reference to developing economies. $8^{\text {th }}$ ed. London: Palgrave-Macmillan, 2005.

. The structure of production, the balance of payments and growth in developing countries: an essay in memory of Mohammed Nureldin Hussain 1954-2005. African Development Review, Apr. 2006.

. The relevance of Keynes today: with particular reference to unemployment in rich and poor countries, 2007. Mimeo.

. (Ed). Keynes and economic development. London: Macmillan, 1987

.; NURELDIN-HUSSAIN, M. The balance of payments constraint, capital flows and growth rate differences between developing countries. Oxford Economic Papers, Nov. 1982.

WARMAN, F.; THIRLWALL, A. P. Interest rates, savings, investment and growth in Mexico 1960-90: tests of the financial liberalisation hypothesis. Journal of Development Studies, Apr. 1994. 